\title{
ע Osatyökykyisten työolot ja työmarkkinasiirtymät kunta-alalla
}

Tutkimme osatyökyvyttömyyseläkkeen saajien eläkesiirtymiä sekä niihin vaikuttavia tekijöitä. Lisäksi tutkimme osatyökyvyttömyyseläkkeelle päätyneiden koettua terveyttä, työkykyä ja työstressitekijöitä. Tutkimukseen osallistuivat Työterveyslaitoksen Kuntasektorin henkilöstön seurantatutkimusaineistosta poimitut osatyökyvyttömyyseläkkeen saajat vuosina 2010-2016 (n=7032). Kevan eläkerekisteristä tunnistettiin tutkimusjoukon kunkin vuoden joulukuussa maksussa olleet eläkkeet eläkelajeittain. Noin puolet osallistujista $(n=3235)$ oli vastannut Kuntasektorin henkilöstön seurantatutkimuksen kyselyihin vähintään kerran. Kyselyvastauksista $80 \%$ oli ennen osatyökyvyttömyyseläkettä ja $20 \%$ sen aikana tai työhön paluun jälkeen. Jälkimmäisistä lähes kaikki olivat vastanneet kyselyihin myös ennen osatyökyvyttömyyseläkettä $(n=798)$. Joka vuosi $10 \%$ osatyökyvyttömyyseläkkeen saajista siirtyi kokoaikaiselle työkyvyttömyysetuudelle; siirtymän todennäköisyyttä lisäsivät krooninen somaattinen sairaus sekä työntekijäasema. Osatyökyvyttömyyseläkkeeltä vanhuuseläkkeelle siirtyi 8-12\% vuosittain. Kuuden seurantavuoden aikana vain 2\% osatyökyvyttömyyseläkkeen saajista palasi kokoaikaisesti töihin; todennäköisemmin nuoremmat ja ylemmät toimihenkilöt. Osatyökyvyttömyysaikana tai kokoaikaiseen työhön paluun jälkeen koettiin useammin työn vaatimien ponnistelujen ja työn palkitsevuuden epäsuhtaa kuin ennen eläkettä. Tutkimus osoitti, että osatyökyvyttömyyseläke voi pidentää osatyökykyisten työuria, vaikka harva palaa kokoaikaiseen työhön. Nuorempi ikä, korkeampi ammatillinen asema, hyvä mielenterveys ja vähäisemmät stressitekijät työssä ennen osatyökyvyttömyyseläkettä näyttäisivät parantavan osa-aikaisen tai kokoaikaisen työssä jatkamisen ennustetta. Kunta-alalla voitaisiin kiinnittää huomiota työhön palanneiden tukemiseen niin, että työ koetaan palkitsevaksi suhteessa työn vaatimiin ponnisteluihin.

ASIASANAT: osatyökyvyttömyyseläke, psykososiaaliset työolot, sosioekonomiset erot, työmarkkinasiirtymät

JENNI ERVASTI, LAURA PEKKARINEN, MARIANNA VIRTANEN, VILLE AALTO, TUULA OKSANEN

\section{YDINASIAT}

- Vaikka osatyökyvyttömyyseläkkeiden määrä kunta-alalla on kasvanut tasaisesti, osatyökykyisten työoloista ja työmarkkinasiirtymistä ei ole aiempaa tutkimustietoa.

- Tutkimus osoitti, että osatyökyvyttömyyseläke voi pidentää osatyökykyisten työuria, vaikka harva palaa kokoaikaiseen työhön.

- Sekä työssä jatkaminen osatyökykyisenä että kokoaikaiseen työhön palaaminen osatyökyvyttömyyseläkkeeltä ovat todennäköisempiä nuoremmilla ja korkeammin koulutetuilla.

- Työntekijät kokivat osatyökyvyttömyysaikana tai kokoaikaiseen työhön paluun jälkeen useammin työn vaatimien ponnistelujen ja työn palkitsevuuden välistä epäsuhtaa kuin ennen osatyökyvyttömyyseläkettä, joten kunta-alalla tulisi kiinnittää huomiota osatyökykyisten ja työhön palanneiden tukemiseen. 


\section{JOHDANTO}

\section{VÄESTÖN IKÄÄNTYMISEN JA KROONISTEN SAIRAUKSIEN HAASTEET KESTÄVÄLLE TYÖURALLE}

Kautta Euroopan väestön ikääntymisen tuomiin haasteisiin pyritään vastaamaan pidentämällä ihmisten työuria.(1,2) Koska ikääntyminen tuo usein mukanaan myös kroonisia sairauksia, huomiota kiinnitetään enenevässä määrin myös sairauksien kanssa elävien jäljellä olevaan työkykyyn ja työuriin. Henkilö, jonka vamma tai sairaus rajoittaa työntekoa määritellään osatyökykyiseksi.(3) Usein osatyökykyisillä on halua jatkaa työssään tai työllistyä.(3) Erityisesti osa-aikatyö kiinnostaa terveysongelmista kärsiviä henkilöitä, jotka ovat työelämän ulkopuolella.(4) Useissa tutkimuksissa ja raporteissa on kuitenkin todettu, että osatyökykyiset ovat muita useammin työttöminä tai muuten työelämän ulkopuolella.(5-9) Maiden välillä on kuitenkin eroja: Pohjoismaisen hyvinvointimallin maissa osatyökykyisten työhön osallistumisen mahdollisuudet ovat paremmat ja osallistumismahdollisuudet ovat tasa-arvoisempia.(9-11)

Suomessa osatyökykyisten työhön osallistumista pyritään tukemaan esimerkiksi kannustamalla työnantajia siihen taloudellisesti, kuten Kelan työterveyshuollon ennaltaehkäisevän toiminnan ja työkykyä ylläpitävän toiminnan korotetuilla korvauksilla.(12) Perustuslain mukaan jokaiselle kuuluu oikeus perustoimeentuloon työttömyyden, sairauden, työkyvyttömyyden ja vanhuuden aikana.(13) Työkyvyttömyyseläke on osa suomalaisten lakisääteistä eläketurvaa.(14) Työeläkejärjestelmän puitteissa on suuria työnantajia sanktioitu aiemmin myönnetyistä työkyvyttömyyseläkkeistä, esimerkkinä tästä on varhaiseläkemenoperusteinen maksu julkisen alan työnantajilla.(15)

Suomen sosiaaliturvajärjestelmässä työkyvyn heikentyessä henkilö voi olla enintään noin vuoden ajan sairauspäivärahalla. Sairauspoissaolon pitkittyessä työnantaja, työntekijä ja työterveyshuolto on kuitenkin velvoitettu jo aiemmin lausumaan työkyvystä ja selvittämään yhteistyössä, voiko työntekijä palata työhönsä ja mitä se työpaikalla vaatii.(16) Jos työkyky ei toimenpiteistä huolimatta palaudu, ammatillinen kuntoutus on aina ensisijainen vaihtoehto eläkkeelle. Työkyvyttömyyseläke voidaan myöntää vasta, kun on varmistettu, että asianmukaiset hoito- ja kuntou- tustoimenpiteet on tehty. Jos henkilön työkyvyttömyys alkaa ikäluokan alimman vanhuuseläkeiän (aiemmin 63 ikävuoden) täyttymisen jälkeen, hänelle myönnetään suoraan vanhuuseläke. Työkyvyttömyyseläke voidaan myöntää joko toistaiseksi tai määräaikaisena kuntoutustukena. Kuntoutustuki myönnetään, jos oletetaan että henkilön työkyky voidaan ainakin osittain kuntoutuksella palauttamaan. Erityisesti nuorille myönnetään usein kuntoutustuki toistaiseksi voimassa olevan työkyvyttömyyseläkkeen sijasta. $(14,17)$

\section{OSATYÖKYYYTTÖMYYSELÄKE TYÖSSÄ JATKAMISEN TUKENA?}

Työssä jatkamista tuetaan työelämässä myös erilaisten osa-aikaisten ratkaisujen, kuten osatyökyvyttömyyseläkkeen turvin. Osatyökyvyttömyyseläkkeellä pyritään pidentämään työuria ja vähentämään kokoaikaiselle työkyvyttömyyseläkkeelle päätymistä. Osatyökyvyttömyyseläkettä voi hakea, jos työkyky on heikentynyt sairauden, vian tai vamman takia. Julkisella sektorilla työkykyä arvioidaan suhteessa omaan ammattiin ja työhön silloin kun hakijalla on työ- tai virkasuhde.(18) Hakemukseen tarvitaan lääkärin lausunto ja siinä huomioidaan työtehtävien vaatimukset, työssä suoriutuminen ja mahdollisuudet toipua työkykyiseksi. Osatyökyvyttömyyseläkkeellä työtulo saa olla enintään $60 \%$ työkyvyttömyyttä edeltäneistä ansioista, mutta työssäkäyntiä ei edellytetä.(19)

Julkisella sektorilla on paljon osatyökyvyttömyyseläkkeitä yksityiseen sektoriin verrattuna. (18) Kunnallisen alan myönnetyt osatyökyvyttömyyseläkkeet ovat lisääntyneet tasaisesti viimeisen 20 vuoden aikana. Vuonna 2016 Kevassa oli vakuutettuna 516708 kunta-alan henkilöä. Heistä 2354 aloitti osatyökyvyttömyyseläkkeen vuonna 2016.(20) Tämä tarkoittaa puolta prosenttia, eli noin viittä henkilöä tuhannesta vakuutetusta. Kuten kokoaikaisissa työkyvyttömyyseläkkeissä, osatyökyvyttömyyseläkkeiden taustalla olevat yleisimmät syyt olivat tuki- ja liikuntaelin sairaudet ja mielenterveyden häiriöt.(20)

Osatyökykyisten hyvinvoinnista ja työelämään osallistumisesta ei kuitenkaan juuri tiedetä. Eläketurvakeskuksen raportin mukaan (kokoaikaista) työkyvyttömyyseläkettä saavista $5 \%$ oli myös työssä, mutta $21 \%$ toivoi pääsevänsä työhön.(21) Yhdysvaltalaisessa tutkimuksessa todettiin, että työtekijät, joilla oli sairaus tai vam- 
ma, raportoivat enemmän syrjintää ja epäoikeudenmukaisuutta kuin muut ja että mielenterveyshäiriöistä kärsivät raportoivat näitä kielteisiä kokemuksia useammin kuin somaattisesti sairaat.(22) Työssä jatkamista kroonisissa kansansairauksissa (masennus, diabetes, sydäntauti) edesauttoivat korkea koulutus ja ammattiasema. $(23,24)$ Pysyvän työkyvyttömyyden riskiin vaikuttivat jossain määrin myös työstressitekijät. $(25,26)$ Tiedetään, että kunta-alalla osatyökyvyttömyyseläkkeet ovat yleistyneet,(27) mutta tutkimustietoa on yhä vähän siitä, missä määrin osatyökyvyttömyyseläkkeeltä siirrytään kokoaikaiseen työkyvyttömyyteen, vanhuuseläkkeelle ja takaisin kokoaikaiseen työsuhteeseen, tai miten terveys, työkyky ja työstressitekijät koetaan ennen osatyökyvyttömyyseläkettä verrattuna kokemukseen osatyökyvyttömyyden aikana tai eläkkeeltä kokoaikaiseen työsuhteeseen palaamisen jälkeen.

Tutkimuksen tavoitteena oli vastata seuraaviin kysymyksiin:

1. Miten osatyökyvyttömyyseläkkeellä olevien työmarkkina- ja eläkepolut etenevät osatyökyvyttömyysetuuden myöntämisen jälkeen?

2. Mitkä tekijät ennustavat eri eläkesiirtymiä ja työhön paluuta?

3. Miten työntekijöiden terveys, työkyky ja stressitekijät eroavat osatyökyvyttömyyseläkkeen saajilla verrattuna muihin kuntasektorintyöntekijöihin?

4. Mitä terveydelle, työkyvylle, ja työstressitekijöille tapahtuu osatyökyvyttömyyseläkkeen aikana tai sen jälkeen verrattuna tilanteeseen ennen osatyökyvyttömyyseläkettä?

\section{AINEISTO, ASETELMA JA MENETELMÄT}

Tutkimuksen perusjoukon muodostavat Työterveyslaitoksen Kuntasektorin henkilöstön seurantatutkimuksen (Kunta10 + Sairaalahenkilöstön hyvinvointitutkimus) osallistujat ( $\mathrm{n}=477509)$. Tämä aineisto kattaa noin $30 \%$ Suomen kuntasektorin työntekijöistä. Kunta10 -tutkimuksessa on mukana kuusi yli 100000 asukkaan kaupunkia ja niiden viisi lähikaupunkia: Espoo, Helsinki, Vantaa, Tampere, Turku, Oulu sekä Raisio, Nokia, Valkeakoski, Naantali ja Virrat. Helsinki oli mukana tutkimuksessa ensimmäistä kertaa vuonna 2014.(28) Kuntasektorin henkilöstön seurantatutkimuksessa mukana on myös Sairaa- lahenkilöstön hyvinvointitutkimuskohortti, jossa seurataan viiden sairaanhoitopiirin tai vastaavan hyvinvointia.(29) Kuntatyöntekijäaineistossa ja sairaalahenkilöstöaineistossa ei ole samoja henkilöitä. Seurantatietoja on vuodesta 1991 alkaen (pl. Helsinki): 2-4 vuoden välein toistuvat kyselyt ja rekisteritiedot (ml. työnantajien rekisterit, Kelan lääkeostojen erityiskorvausoikeusrekisteri, syöpärekisteri). Rekisteritiedot on yhdistetty kyselyvastauksiin niiden vastaajien osalta, jotka ovat antaneet suostumuksen yhdistämiseen. Tutkimusprojektit ovat saaneet puoltavan lausunnon Helsingin ja Uudenmaan sairaanhoitopiirin koordinoivasta eettisestä toimikunnasta.

Tämän tutkimuksen joukko rajattiin niihin tutkimuskohorttiin kuuluviin, jotka jäivät osatyökyvyttömyyseläkkeelle vuosina 2010-2016. Tieto osatyökyvyttömyyseläkkeestä haettiin Kevan KuEL-rekisteristä. Kevan eläkerekistereistä (KuEL) seurattiin osatyökyvyttömyyseläkkeelle siirtyneiden siirtymiä muunlaiselle eläkkeelle (kuntoutustuki/työkyvyttömyyseläke/osa-aikaeläke/vanhuuseläke) tai työhön paluuta 1-6 vuotta osatyökyvyttömyyseläkkeelle siirtymisestä. Lisäksi tutkittiin, miten ikä, sukupuoli, ammattiasema ja somaattiset sairaudet selittävät siirtymiä. Tässä osatutkimuksessa tutkimusjoukon koko oli 7032 henkilöä.

Kyselytietoja oli saatavilla osatyökyvyttömyyseläkettä edeltävistä kyselyistä ja osatyökyvyttömyysajalta (jos vastaaja oli osatyökyvyttömyyseläkkeellä ollessaan vähintään $50 \%$ työsuhteessa) sekä vastaajan palattua kokoaikaiseen työhön osatyökyvyttömyyseläkkeen jälkeen. Vuosina 2000-2016 kyselyihin oli vastannut 3235 osatyökyvyttömyyseläkkeelle 2010-2016 jäänyttä työntekijää. Ennen osa-aikaeläkettä heistä vastasi 3231 henkilöä ja osa-aikaeläkkeen aikana/jälkeen 802 henkilöä. Sekä ennen että aikana/jälkeen vastasi 798 henkilöä. Tutkimusjoukko kuvataan tutkimuskysymyksittäin Kuvassa 1.

\section{MITTARIT}

Eläkestatus/työmarkkinatilanne: KuEL-rekisteristä poimittiin tutkimusjoukkoon kuuluvien kuntien työntekijöiden eläketiedot vuosittain (joulukuussa maksussa olevat) ja eläkelajeittain 20102016. Eläkelajit olivat osatyökyvyttömyyseläke (sis. osakuntoutustuen), kuntoutustuki, täysi työkyvyttömyyseläke, osa-aikaeläke ja vanhuuseläke. Eläkelajit yhdistettiin niin, että kuntoutustuki 


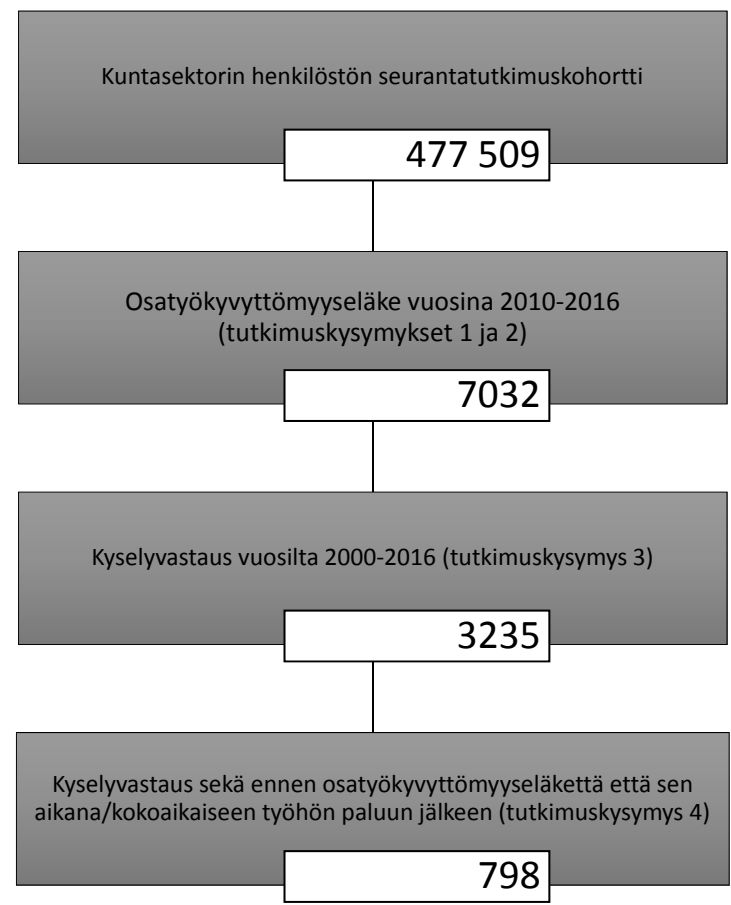

Kyselytietoja 2-4 vuoden välein vuodesta 2000 alkaen

Rekisteriseuranta vuodesta 1991 alkaen

Kevan eläkerekisterissä joulukuussa maksussa olleet eläkkeet eläkelajeittain ja vuosittain

$80 \%$ vastaus ennen osatyökyvyttömyyseläkettä $20 \%$ sen aikana tai kokoaikaiseen työhön paluun jälkeen

Kuva 1. Tutkimusjoukko tutkimuskysymyksittäin.

(määräaikainen työkyvyttömyyseläke), yhdistettiin työkyvyttömyyseläkkeeseen. Osa-aikaeläke (vuodesta 2017 alkaen osittainen varhennettu vanhuuseläke) yhdistettiin vanhuuseläkkeeseen. Työhön paluu määriteltiin niin, että osatyökyvyttömyyseläkkeen päättymisen jälkeen rekistereistä ei löytynyt mitään eläkepäätöstä. Sen sijaan päättymisen jälkeen seuraavilta vuosilta piti löytyä vähintään yksi kokoaikainen henkilötyökuukausi. "Ei tietoa" -ryhmään päätyivät ne, joilta ei löytynyt seurantatietoa eläkepäätöksistä tai henkilötyökuukausista. Tähän ryhmään sisältyivät kuolleet, työpaikkaa vaihtaneet ja irtisanotut.

Krooniset somaattiset sairaudet: Erityiskorvausoikeusrekisteristä poimittiin seuraaviin sairauksiin liittyvät erityiskorvattavat lääkeostot: diabetes, sydämen vajaatoiminta, sepelvaltimotauti, krooninen verenpainetauti, nivelreuma ja keuhkoastma. Lisäksi syöpärekisteristä poimittiin syöpätapaukset.

Taustamuuttujat: Ikä (syntymävuosi) ja sukupuoli saatiin työnantajien rekistereistä. Tilastokeskuksen rekistereistä poimittiin tiedot tutkimusjoukkoon kuuluvien ammattiluokituksesta. Ammattiluokitus jaettiin ylempiin toimihenkilöihin (johtajat, erityisasiantuntijat, asiantuntijat), alem- piin toimihenkilöihin (toimisto-, asiakaspalvelu-, palvelu-, myyntityö) ja työntekijöihin (rakennus-, korjaus-, ja kuljetustyö ja muut työntekijät).

Terveys ja työkyky (kyselyaineisto): Koettua terveyden tilaa mitattiin yhdellä kysymyksellä, jossa vastausvaihtoehdot vaihtelivat asteikolla 1-5 hyvästä (1) huonoon (5). Tilastollisessa mallinnuksessa se luokiteltiin kahteen luokkaan hyvä/kohtuullinen (1-3) vs. huono (4-5). Psyykkistä rasittuneisuutta mitattiin General Health Questionnaire -mittariston avulla (GHQ-12). (30) GHQ-12:ssa vastaajat arvioivat missä määrin 12 psyykkistä oireilua kuvaavaa lausumaa kuvaa itseään. Vaihtoehdot "ei kuvaa ollenkaan" ja "kuvaa hieman" saivat arvon 0 ja vaihtoehdot "kuvaa hyvin" ja "kuvaa erittäin hyvin" saivat arvon 1. Näin ollen muuttuja voi saada arvoja välillä 0-12. Katkaisukohdaksi psyykkiselle rasittuneisuudelle valittiin vakiintuneen käytännön mukaisesti vähintään 4 pistettä. Koettu työkyky sai arvoja 0 ja 10 väliltä. Tilastollisessa mallinnuksessa huono työkyky määriteltiin aiemman tutkimuksen perusteella arvoihin alle 6.(31)

Psykososiaaliset työstressitekijät (kyselyaineisto): Kuormittava työ määriteltiin Karasekin ja Theorellin työstressi-mittarin avulla, jossa kuor- 
Taulukko 1. Osatyökyvyttömyyseläkkeelle siirtyneet (alkavat osatyökyvyttömyyseläkkeet) tutkimusaineistossa ja kuntaalalla

\begin{tabular}{|l|c|c|c|}
\hline & Tutkimusaineisto & Kunta-ala yhteensä $*$ & $\begin{array}{l}\text { Tutkimusaineisto/ } \\
\text { Kunta-ala yhteensä }\end{array}$ \\
\hline $2010 * *$ & 2339 & - & - \\
\hline 2011 & 761 & 2054 & $37 \%$ \\
\hline 2012 & 608 & 1704 & $36 \%$ \\
\hline 2013 & 825 & 2317 & $36 \%$ \\
\hline 2014 & 852 & 2204 & $36 \%$ \\
\hline 2015 & 792 & 2181 & $36 \%$ \\
\hline
\end{tabular}

* Kunta-alan palveluksesta osatyökyvyttömyyseläkkeelle siirtyneet henkilöt (Kevan eläkerekisteri)

** Vuoden 2010 luku sisältää kaikki vuonna 2010 joulukuussa maksussa olleet osatyökyvyttömyyseläkkeet eikä ole täten verrannollinen muhin lukuihin.

mitus syntyy työpaineiden ja vähäisen työn hallinnan epätasapainosta.(32) Kyselyssä oli 3 työpaineita ja 9 työn hallintaa kuvaavaa väittämää. Tilastollisessa mallinnuksessa työstressi määriteltiin tilanteena, jossa työpaineet ylittävät mediaaniarvon ja työn hallinta alitti mediaanin. Lisäksi tutkimme ponnistelujen ja työn palkitsevuuden epäsuhtaa.(33) Kyselyn epäsuhta-mittarissa on yksi ponnisteluja kuvaavaa kysymys ("Kuinka paljon koet panostavasi kysyjäsi ja voimiasi työhön?”) ja kolme palkitsevuuskysymystä ("Kuinka paljon koet saavasi itsellesi vastinetta työstäsi 1) tuloina, työsuhde-etuina yms.? 2) tunnustuksena ja arvostuksena? ja 3) henkilökohtaisena tyydytyksenä?”). Tilastollisessa mallinnuksessa epäsuhtaa kuvattiin mediaaniarvoon perustuen kaksiluokkaisena (kyllä/ei).

\section{TILASTOLLINEN ANALYYSI}

Aineiston yleiseen kuvailuun käytettiin frekvenssejä ja keskiarvoja. Eläkesiirtymiä kuvattiin trace plot-kuvalla (myös heat map, lämpökartta). Algoritmin ideana on mitata eläkesiirtymien samankaltaisuutta ja löytää jokaisen yksilön eläkesiirtymiin optimaalinen paikka kuvassa.(34) Aineisto järjestettiin henkilöittäin vuositasolla ylhäältä alas seuraavasti: 1) ei eläkkeellä, 2) osatyökyvyttömyyseläke, 3) kokoaikainen työkyvyttömyyseläke/ kuntoutustuki, 4) vanhuuseläke/osaaikaeläke alkaen vuodesta 2010 ja ehdolla seuraava vuosi on edellisen vuoden luokituksen "sisällä". Kuvan piirtämiseen ja siihen liittyvään datan käsittelyyn käytettiin R-ohjelman haven-, reshape2-, ggplot2kirjastoja.

Rekisteriaineiston eläkesiirtymiin yhteydessä olevia tekijöitä tutkittiin multinomiaalisella lo- gistisella regressioanalyysilla, jossa offset-muuttujana oli seuranta-ajan logaritmi. Näin voitiin huomioida yksilöiden eripituiset seurantaajat. Kokoaikaiselle työkyvyttömyysetuudelle, vanhuuseläkkeelle ja kokoaikaiseen työhön siirtymisiä verrattiin osatyökyvyttömyyseläkkeellä pysyviin.

Kyselyaineiston toistomittausanalyysissa käytettiin yleistettyjä lineaarisia malleja (generalized linear models, SAS proc GENMOD) ja logbinomial-jakaumaa, joka tuotti esiintyvyyssuhteet (PR, Prevalence Ratio) ja niiden 95 \% luottamusvälit. Aika oli huomioitu niin, että kyselyn ajankohta oli kovariaattina. Muina sekoittavina tekijöinä huomioitiin ikä, sukupuoli, ammattiasema ja työaikamuoto.

\section{TULOKSET}

\section{AINEISTON EDUSTAVUUS SUHTEESSA KUNTA-ALAN VAKUUTETTUIHIN YHTEENSÄ}

Taulukko 1 kuvaa osatyökyvyttömyyseläkkeelle siirtyneiden määriä tutkimusaineistossamme ja suhteessa koko kunta-alaan. Tutkimusaineistomme kattoi vuosittain noin $36 \%$ kaikista kuntaalan osatyökyvyttömyyseläkkeelle siirtyneistä (=alkavista osatyökyvyttömyyseläkkeistä).

\section{OSATYÖKYYYTTÖMYYSELÄKKEEN SAAJIEN TYÖMARKKINA- JA ELÄKESIIRTYMÄT}

Työmarkkina- tai eläkestatus määriteltiin ensimmäisestä siirtymästä pois osatyökyvyttömyyseläkkeeltä. Vuoteen 2016 mennessä, $26 \%$ tutkimusjoukosta oli siirtynyt vanhuuseläkkeelle, $23 \%$ täydelle työkyvyttömyyseläkkeelle tai kuntoutus- 


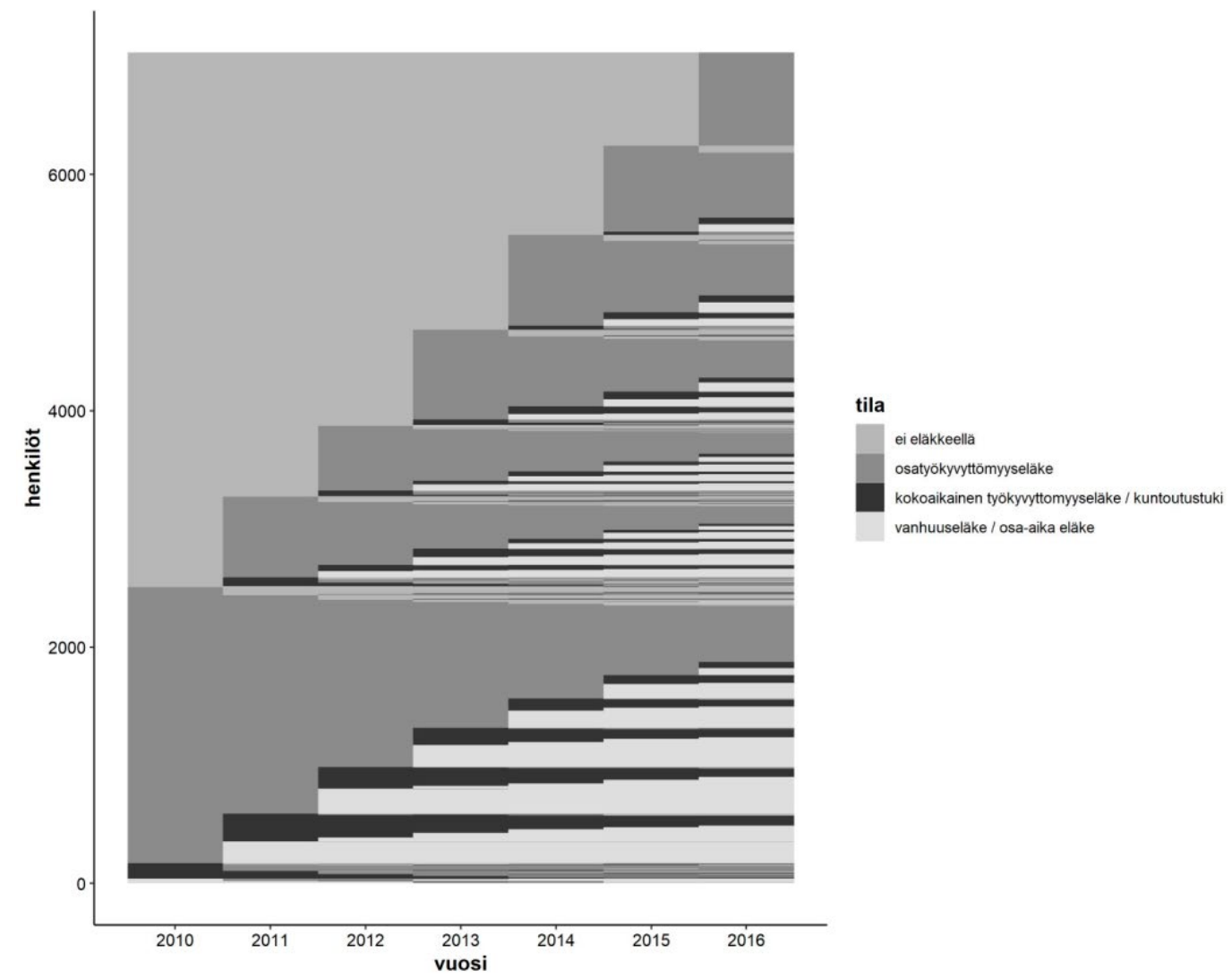

Kuva 2. Eläkesiirtymät tutkimusaineistossa vuosina 2011-2016. Trace plot-kuvaaja.(27) Eri sävyillä on merkitty henkilöiden eläkestatus. Tutkimusaineisto on järjestetty vuosittain niin, että kukin harmaa porras kertoo kyseisen vuoden joulukuussa maksussa olleesta osatyökyvyttömyyseläkkeestä. Mustat portaat kertovat kyseisen vuoden joulukuussa maksussa olleesta kokoaikaisesta työkyvyttömyyseläkkeestä ja vaaleat portaat vanhuuseläkkeestä. Vaalean harmaalla on merkitty 'ei eläkkeellä' status.

tuelle ja $2 \%$ oli palannut takaisin työhön tutkimuskuntiin. Vähän alle puolet (45\%) oli edelleen osatyökyvyttömyyseläkkeellä. Neljälle prosentille ei löytynyt eläkepäätöstä, muttei myöskään henkilötyökuukausia. Tässä ryhmässä olivat työttömyysetuudelle päätyneet, työelämän ulkopuolelle ilman edellä mainittuja tukimuotoja siirtyneet, muualle kuin kunta-alan tutkimusorganisaatioihin työhön palanneet ja seuranta-aikana kuolleet. Edellä mainittuja prosenttiosuuksia tarkasteltaessa on huomioitava, että seuranta-aika oli tutkittavilla eri pituinen (vuonna 2016 eläkkeelle siirtyneet eivät edes ole voineet siirtyä muuhun statukseen) ja siksi 'osatyökyvyttömyyseläkkeelle jääneet' -joukko on ikään kuin yliedustettuna. Sairaalakohorttiin kuuluneille ei ollut tietoa henkilötyökuukausista ja siksi he eivät edes voineet kuulua 'työhön paluu' ryhmään, vaan eläketiedon puuttuessa he kirjautuivat 'ei tietoa' ryh- mään. Näistä syistä seuraavaksi kuvaamme tutkimusjoukon työmarkkinasiirtymiä ja eläkepolkuja tarkemmin vuosittain.

Kuvassa 2 tutkittavat henkilöt $(\mathrm{n}=7032)$ on kuvattu pystyakselilla ja seuranta-aika vaakaakselilla. Vuonna 2010 osatyökyvyttömyyseläkkeellä oli kolmasosa tutkimusjoukosta $(n=2339)$ ja heistä noin $20 \%$ pysyi osatyökyvyttömyyseläkkeellä koko seurannan ajan. Vuosi 2010 sisältää siis kaikki joulukuussa 2010 maksussa olleet eläkkeet, eli ainoastaan kyseisenä vuonna alkavia. Vuodesta 2011 eteenpäin portaat kuvaavat alkavia eläkkeitä. Alkavissa osatyökyvyttömyyseläkkeissä oli hienoista kasvua vuosina 2011-2016 (ks. myös Taulukko 1). Osatyökyvyttömyyseläke vaihtui kokoaikaiseen työkyvyttömyystukeen (=työkyvyttömyyseläke/kuntoutustuki) noin 10 prosentilla vuosittain. 8-12 prosentilla osatyökyvyttömyyseläke vaihtui vuosit- 
Taulukko 2. Ensimmäisen siirtymän tai seurannan lopun työmarkkina-/eläkestatus taustatekijöiden mukaan.

\begin{tabular}{|l|c|c|c|c|c|}
\hline & $\begin{array}{c}\text { Osatyökyvyttömyys- } \\
\text { eläke jatkuu }\end{array}$ & $\begin{array}{c}\text { Kokoaikainen } \\
\text { työkyvyttömyysetuus }\end{array}$ & Vanhuuseläke & $\begin{array}{c}\text { Kokoaikaiseen } \\
\text { työhön paluu }\end{array}$ & Kaikki \\
\hline Nainen, \% & 88 & 85 & 85 & 87 & 87 \\
\hline Mies, \% & 12 & 15 & 15 & 13 & 13 \\
\hline Keski-ikä & 54 & 54 & 60 & 56 & 55 \\
\hline $\begin{array}{l}\text { Ylempi } \\
\text { toimihlö, \% }\end{array}$ & 37 & 33 & 31 & 37 & 46 \\
\hline $\begin{array}{l}\text { Alempi } \\
\text { toimihlö, \% }\end{array}$ & 46 & 44 & 49 & 15 & \\
\hline Työntekijä, \% & 17 & 23 & 20 & 72 & 62 \\
\hline $\begin{array}{l}\text { Ei som. } \\
\text { sairautta, \% }\end{array}$ & 64 & 57 & 61 & & 28 \\
\hline $\begin{array}{l}\text { Somaattinen } \\
\text { sair., \% }\end{array}$ & 36 & 43 & 39 & & 38 \\
\hline
\end{tabular}

Taulukko 3. Ensimmäisen siirtymän tai seurannan lopun työmarkkina-/eläkestatukseen yhteydessä olevat tekijät. Multinomiaalinen logistinen regressio, jossa referenssiluokkana 'osatyökyvyttömyyseläke jatkuu' ( $\mathrm{n}=976,47 \%$ ). Vetosuhde (odds ratio, OR) ja estimaatin $95 \%$ luottamusvälit (confidence interval, CI).

\begin{tabular}{|c|c|c|c|c|c|c|}
\hline & \multicolumn{2}{|c|}{$\begin{array}{l}\text { Kokoaikaiselle } \\
\text { työkyvyttömyysetuudelle } \\
\text { n=447 }(21 \%)\end{array}$} & \multicolumn{2}{|c|}{$\begin{array}{l}\text { Vanhuuseläkkeelle } \\
n=617(29 \%)\end{array}$} & \multicolumn{2}{|c|}{$\begin{array}{l}\text { Paluu kokoaikatyöhön } \\
n=52(2,5 \%)\end{array}$} \\
\hline & OR & $95 \%$ CI & OR & $95 \% \mathrm{CI}$ & OR & $95 \% \mathrm{CI}$ \\
\hline Mies (=ref) & 1 & & 1 & & 1 & \\
\hline Nainen & 0.76 & $0.54,1.07$ & 0.82 & $0.56,1.22$ & 1.15 & $0.43,3.08$ \\
\hline Ikä/1 v & 1.04 & $1.01,1.06$ & 2.30 & $2.14,2.47$ & 0.91 & $0.88,0.95$ \\
\hline Ylempi toimihlö (=ref) & 1 & & 1 & & 1 & \\
\hline Alempi toimihlö & 0.94 & $0.72,1.24$ & 1.01 & $0.75,1.35$ & 0.58 & $0.32,1.07$ \\
\hline Työntekijä & 1.80 & $1.30,2.48$ & 1.16 & $0.80,1.68$ & 0.28 & $0.08,0.97$ \\
\hline Ei som. sairautta (=ref) & 1 & & 1 & & 1 & \\
\hline Som. sairaus & 1.61 & $1.27,2.04$ & 1.25 & $0.96,1.64$ & 0.79 & $0.42,1.51$ \\
\hline
\end{tabular}

tain vanhuuseläkkeeseen (vanhuuseläke/aikaaikaeläke eli varhennettu vanhuuseläke). Osatyökyvyttömyyseläkkeen saajista $3-4 \%$ palasi tilaan 'ei eläkkeellä'. Tämä ryhmä sisältää työmarkkinoiden käyttöön palanneet (ml. kokoaikaiseen työhön palanneet $2 \%$ ja työttömyystuelle siirtyneet), mutta myös seurannan aikana kuolleet. Portaita vertailemalla havaitaan, ettei eri vuosina osatyökyvyttömyyseläkkeelle jääneiden välillä ollut juuri suhteellisia eroja eläkesiirtymissä. (Kuva 2.)

\section{MITKÄ TEKIJÄT SELITTÄVÄT ERI ELÄKESIIRTYMIÄ?}

Taulukossa 2 on esitetty ensimmäinen siirtymä pois osatyökyvyttömyyseläkkeeltä tai seurannan lopun eläke- tai työmarkkinastatus taustatekijöittäin ryhmiteltynä. Taulukossa 3 tilastollisessa mallinnuksessa kaikki tekijät on syötetty malliin yhtä aikaa, eli niiden vaikutus toisiinsa on huomioitu. Lisäksi mallissa on huomioitu osatyö- kyvyttömyyseläkkeen kesto (=offset-muuttuja). Eläkesiirtymiä ja kokoaikaiseen työhön paluuta verrataan heihin, jotka olivat osatyökyvyttömyyseläkkeellä seurannan loppuun. Sukupuoli ei ollut yhteydessä eläkesiirtymiin eikä työhön paluuseen. Kokoaikaiselle työkyvyttömyysetuudelle $(\mathrm{OR}=1,0495 \%$ CI 1,01-1,06) ja vanhuuseläkkeelle (OR=2,30 95\% CI 2,14-2,47) siirtyneet olivat vanhempia, ja kokoaikaiseen työhön palanneet olivat nuorempia $(\mathrm{OR}=0,91$ 95\% CI 0,88-0,95) verrattuna heihin, joilla osatyökyvyttömyyseläke jatkui seurannan loppuun. Kokoaikaiselle työkyvyttömyysetuudelle siirtyneet olivat useammin työntekijäasemassa $(\mathrm{OR}=1,80$ $95 \%$ CI 1,30-2,48). Heillä myös työhön paluu oli kaikkein epätodennäköisintä (OR=0,28 95\% CI 0,08-0,97). Somaattinen krooninen sairaus oli yhteydessä kokoaikaiselle työkyvyttömyysetuudelle siirtymiseen (OR=1,61 95\% CI 1,27-2,04). (Taulukko 3.) 
Taulukko 4. Osatyökyvyttömyyseläkkeen saajat, jotka vastasivat kyselyyn joko ennen eläkettä tai sen aikana/työhön paluun jälkeen. ka=keskiarvo

\begin{tabular}{|l|l|l|l|l|}
\hline & $\begin{array}{l}\text { Ennen eläkettä } \\
\text { n=3102-3231 }\end{array}$ & $\begin{array}{l}\text { Eläkkeen aikana/ } \\
\text { työhön paluun jälkeen } \\
\text { n=772-802 }\end{array}$ & $\begin{array}{l}\text { Ryhmien välisen } \\
\text { eron merkitsevyys } \\
\text { (Chi2/t-testi) }\end{array}$ & Vertailuaineisto* \\
\hline Naiset, \% & 88 & 88 & 0.64 & 82 \\
\hline Ikä, ka & 52 & 58 & $<0.001$ & 50 \\
\hline Ylempi toimihenkilö, \% & 39 & 41 & $<0.001$ & 63 \\
\hline Alempi toimihenkilö, \% & 38 & 43 & & 28 \\
\hline Työntekijä, \% & 23 & 16 & & 9 \\
\hline Hyvä koettu terveys, \% & 35 & 18 & $<0.001$ & 74 \\
\hline Työkyky (0-10), ka & 6 & 5 & $<0.001$ & 8 \\
\hline Psyykkistä oireilua, \% & 39 & 29 & $<0.001$ & 20 \\
\hline Työn kuormittavuus, ka & 1.03 & 0.98 & 0.002 & 0.89 \\
\hline $\begin{array}{l}\text { Ponnistelu-palkitsevuus } \\
\text { epäsuhta, ka }\end{array}$ & 1.68 & 1.63 & 0.05 & 1.55 \\
\hline
\end{tabular}

* vertailuaineisto: kaikki 2012 vastanneet

Taulukko 5. Muutos koetussa terveydessä, työkyvyssä ja työstressitekijöissä eläkkeen aikana tai sen jälkeen kyselyyn vastanneilla (referenssiluokka=ennen eläkettä). Ikä, sukupuoli, ammattiasema, työaikamuoto ja kyselyvuosi on vakioitu. Vain sekä ennen että aikana/jälkeen vastanneet ( $\mathrm{n}=794-796)$.

\begin{tabular}{|l|l|l|l|l|l|}
\hline & & & \multicolumn{2}{|l|}{ Vakioitu prevalenssi } \\
\hline & $\mathbf{N}_{\text {havainnot }}\left(\mathbf{n}_{\text {tapaukset }}\right)$ & PR & $\mathbf{9 5} \%$ luottamusväli & Ennen & Jälkeen \\
\hline Heikko itsearvioitu terveys & $1532(510)$ & 1.37 & $1.02,1.83$ & $30 \%$ & $39 \%$ \\
\hline Psyykkinen oireilu & $1535(519)$ & 0.83 & $0.66,1.05$ & $34 \%$ & $28 \%$ \\
\hline Heikko itsearvioitu työkyky & $1528(656)$ & 1.25 & $1.13,1.38$ & $38 \%$ & $49 \%$ \\
\hline Kuormittava työ & $1524(378)$ & 0.93 & $0.71,1.21$ & $22 \%$ & $20 \%$ \\
\hline Ponnistelu-palkitsevuus epäsuhta & $1508(603)$ & 1.29 & $1.06,1.57$ & $33 \%$ & $43 \%$ \\
\hline
\end{tabular}

\section{MITKÄ TEKIJ̈̈T KUVAAVAT OSATYÖKYYYTTÖMYYSEL̈̈KKEELLE PÄ̈̈TYNEITÄ ENNEN ELÄKEPÄ̈̈TÖSTÄ VS. SEN AIKANA TAI TYÖHÖN PALUUN JäLKEEN?}

Osatyökyvyttömyyseläkkeen saajia joille löytyi myös kyselytietoja, oli yhteensä 3235 henkilöä. Taulukossa 4 kuvataan osatyökyvyttömyyseläkkeen saajia sen mukaan, ovatko he vastanneet kyselyyn ennen eläkettä vai sen aikana tai työhön paluun jälkeen. Vertailujoukoksi on otettu kaikki vuoden 2012 kyselyyn vastanneet, koska se oli tutkimuksen kohdejoukossa tyypillisin kyselyvastausvuosi. Verrattuna kaikkiin vastaajiin, osatyökyvyttömyyseläkkeelle päätyneet (sekä ennen että aikana/jälkeen vastanneet) olivat hieman useammin naisia, vanhempia ja alemmissa ammattiasemissa. Osatyökyvyttömyyseläkkeelle päätyneet kokivat terveytensä heikommaksi, heillä oli enemmän psyykkistä oireilua sekä heikompi työkyky kuin vertailuryhmässä. Lisäksi he koki- vat työssään enemmän stressitekijöitä kuin vertailuryhmä.

Taulukossa 5 kuvataan muutosta terveys-, työkyky- ja stressitekijöissä niiden vastaajien joukossa, jotka vastasivat kyselyyn sekä ennen osatyökyvyttömyyseläkettä että sen aikana/jälkeen. Terveys (PR=1,37 95\% CI 1,02-1,83) ja työkyky (PR=1,25 95\% CI 1,13-1,38) heikkenivät seurannassa. Psyykkisen oireilun muutos ei ollut tilastollisesti merkitsevä, eikä työkuormituksen kokemuksen vähentyminen. Ponnistelu-palkitsevuus epäsuhta kasvoi kyselyvastausten välissä ( $\mathrm{PR}=1,2995 \%$ CI 1,06-1,57).

\section{POHDINTA}

Tutkimuksessamme havaittiin, että vuosittain noin joka kymmenes osatyökyvyttömyyseläkkeen saaja siirtyi vanhuuseläkkeelle, saman verran siirtyi kokoaikaiselle työkyvyttömyyseläkkeelle ja noin 
3-4 \% palasi takaisin työmarkkinoiden käyttöön. Lopuilla 75 prosentilla ei rekisteröity eläkesiirtymää vuoden aikana. Vuosittaisissa siirtymissä ei ollut juuri vaihtelua kuuden seurantavuoden aikana. Vuonna 2010 osatyökyvyttömyyseläkkeellä olleista noin viidennes jatkoi osatyökyvyttömyyseläkkeellä seurannan loppuun. Olemme aiemmin raportoineet osatyökyvyttömyyseläkkeellä olevien työskentelystä vuonna 2016 kuudessa suurimmassa kunnassa ja havaitsimme, että vain 15 prosentilla ei ollut lainkaan työssäoloa.(35) Osa-aikainen työskentely osatyökyvyttömyyseläkkeellä ja toisaalta vanhuuseläkkeelle siirtyminen osatyökyvyttömyyseläkkeeltä kertovat, että osatyökyvyttömyyseläke voi tukea työssä jatkamista ja työuraa sairauksista huolimatta.

Kuuden seurantavuoden aikana neljännes tutkimusjoukon osatyökyvyttömyyseläkkeen saajista siirtyi vanhuuseläkkeelle. Hiukan alle neljännekselle osatyökyvyttömyyseläke ei ollut riittävä keino selviytyä työssä, tai sairaus paheni seurannan aikana ja he siirtyivät kokoaikaiselle työkyvyttömyysetuudelle. Kokoaikaiselle työkyvyttömyyseläkkeelle siirtymisen todennäköisyyttä lisäsivät krooninen somaattinen sairaus sekä työntekijäasema. Tämä tukee aiempaa näyttöä, että sosioekonominen asema (koulutus, tulotaso ja ammattiasema) vaikuttaa pitkältä poissaololta paluun todennäköisyyteen.(36) Toisaalta tässä joukossa todennäköisesti pidennettiin työuraa osatyökyvyttömyysjakson verran. Vain noin kaksi prosenttia tutkimusjoukosta palasi koko seurannan aikana takaisin kokoaikaiseen työhön tutkimuskuntiin. Tämä luku on kuitenkin aliestimaatti, koska sairaalakohortin kohdalla ei ollut tietoa henkilötyökuukausista ja eläketiedon puuttuessa he siirtyivät "ei tietoa" -ryhmään. Palaaminen kokoaikaiseen työhön oli todennäköisempää nuoremmilla ja ylemmillä toimihenkilöillä verrattuna vanhempiin ja työntekijäasemassa oleviin.

Noin viisi tuhannesta kunta-alan työeläkevakuutetusta siirtyi osatyökyvyttömyyseläkkeelle vuosittain vuosina 2011-2016, ja rekisteritutkimusaineistomme kattoi näistä henkilöistä reilun kolmanneksen. Vuoden 2010 osalta mukana olivat kaikki joulukuussa maksussa olleet eläkkeet, eli myös aiemmin alkaneet. Kyselyaineisto saatiin yhdistettyä 3235 vastaajan osalta, mikä oli $46 \%$ rekisteriaineistosta. Verrattuna kaikkiin kuntasektorin kyselytutkimukseen vastan- neisiin, osatyökyvyttömyyseläkkeen saajat kokivat terveytensä, työkykynsä ja stressitekijät työssään kielteisemmin. Muutos ponnistelujen ja palkitsemisen suhteessa oli kielteinen niiden vastaajien joukossa, jotka vastasivat kyselyyn sekä ennen osatyökyvyttömyyseläkettä, että sen aikana tai kokoaikaiseen työsuhteeseen paluun jälkeen. Voi siis olla, että osatyökykyisten kokoja osa-aikaiseen työskentelyyn voidaan vaikuttaa kiinnittämällä huomioita psykososiaaliseen työympäristöön. Tätä olettamusta tukevat aiemmat tutkimukset, joissa on todettu psykososiaalisten stressitekijöiden olevan yhteydessä työkykyyn ja työhön osallistumiseen kroonisesti sairastavilla. $(25,26,37)$

Tutkimuksen vahvuutena olivat edustava otos suomalaisista kuntatyöntekijöistä, luotettavat rekisteritiedot ja kuuden vuoden rekisteriseuranta. Tulosten yleistettävyys yli kunta-alan on kuitenkin epäselvää. Vaikka eläkerekisteritiedot olivat luotettavia, meillä oli tieto ainoastaan joulukuussa maksussa olleista eläkkeistä. Emme siis tienneet tarkkaa eläkkeen alku- ja loppupäivämäärää. Tästä syystä emme voineet varmistaa oliko vastaaja vastannut kyselyyn osatyökyvyttömyyseläkkeen aikana vai kokoaikaiseen työhön paluun jälkeen ja jouduimme yhdistämään nämä ryhmät. Tapaus-verrokkiasetelmassa olisimme voineet vielä tarkemmin tutkia, tapahtuiko kielteinen muutos ponnistelujen ja palkitsemisen suhteessa vain osatyökyvyttömyyseläkkeelle päätyneiden joukossa, vai oliko kyseessä kenties yleisempi trendimuutos ajassa. Tämä ei kuitenkaan ollut tämän tutkimuksen tavoitteena ja vaatii jatkotutkimuksia. Osatyökyvyttömyyseläkkeelle päätyneet arvioivat työstressitekijänsä kuitenkin kielteisemmin kuin kunta-alan vastaajajoukko keskimäärin.

\section{JOHTOPÄÄTÖKSET}

Osatyökyvyttömyyseläke vaikuttaa olevan väylä pidentää osatyökykyisten työuria, vaikka harva palaa kokoaikaiseen työhön. Nuorempi ikä ja korkeampi ammatillinen asema näyttäisivät parantavan kokoaikaiseen työhön paluun ennustetta. Osatyökyvyttömyyseläkkeen aikana on syytä tukea työssä jatkamista ja huolehtia osatyökykyisen työ- ja toimintakyvystä. Kunta-alan työpaikoilla tulisi kiinnittää huomioita myös työhön paluun tukemiseen siten, että osatyökyvyttömyyseläkkeeltä kokoaikaiseen työhön palanneet voi- 
vat kokea työn palkitsevaksi sen vaatimista ponnisteluista huolimatta. Ennen kaikkea, työpaikoilla tulee kuitenkin kiinnittää huomiota työoloihin ja yhdessä työnantajan, työntekijöiden ja työterveyshuollon kesken sopia toimenpiteistä, joilla henkilöstön työkykyä tuetaan varhaisessa vaiheessa, ennen työkyvyttömyyden uhkaa.

\section{KIITOKSET:}

Kiitämme tilastotieteilijä Aki Koskista Trace plot-kuvaajasta.

\section{RAHOITUS:}

Tutkimuksen on rahoittanut Keva. Jenni Ervasti on saanut rahoitusta myös Työsuojelurahastolta (\#118066).

\section{KIRJOITTAJIEN KONTRIBUUTIOT:}

Ervasti on vastuukirjoittaja ja teki analyysit sekä laati käsikirjoituksen. Pekkarinen mahdollisti Kevasta saadun rekisteriaineiston ja osallistui käsikirjoituksen muokkaamiseen. Virtanen osallistui tutkimusasetelman suunnitteluun ja käsikirjoituksen kriittiseen kommentointiin. Aalto osallistui tutkimusasetelman suunnitteluun, yhdisti aineistot ja auttoi analyyseissa. Oksanen on Kuntahenkilöstön seurantatutkimuksen johtaja ja osallistui tutkimusasetelman suunnitteluun sekä käsikirjoituksen kommentointiin.

\section{Ervasti, J., Pekkarinen, L., Virtanen, M., Aalto,V., Oksanen, T. Labor market transitions and working conditions among partially disabled public sector employees. Sosiaalilääketieteellinen aikakauslehti - Journal of Social Medicine 2019: 56: 15-26.}

We examined the labor market transitions of public sector employees in part-time disability pension (DP), and the associations of health- and stress-related factors with part-time DP compared to public sector employees in general. The participants were from the Finnish Public Sector (FPS) study cohort, who ended up on part-time DP during 2010-2016 ( $\mathrm{n}=7032$ ). About 50\% of the participants $(n=3235)$ had responded to an FPS survey. Of these survey responses, $80 \%$ were before part-time DP, and $20 \%$ were during part-time DP or after returning to work. For 798 participants, we could match a before-survey response (T1) to a during/after survey response (T2). A total of $10 \%$ of those receiving a parttime DP, moved on to full-time DP each year. The probability of this transition was higher among those with a chronic somatic disease and a lower socioeconomic position. Each year, 8-12\% made a transition from part-time DP to old-age pension. About 2\% returned to full-time work during the six-year follow-up; this transition was more likely among younger than older and among people in high rather than low socioeconomic position. Probability of effort-reward imbalance at work was higher at T2 than at T1. We showed that part-time DP can lengthen the work career of the disabled. Attention could be paid to return to work policies which support the balance between efforts and rewards.

Keywords: labor market transitions, part-time disability pension, psychosocial working conditions, socioeconomic gradient

Saapunut 13.02.2018

Hyväksytty 08.09.2018

\section{LÄHTEET}

(1) Wahrendorf M, Akinwale B, Landy R, ym. Who in Europe Works beyond the State Pension Age and under which Conditions? Results from SHARE. J Popul Ageing 2017;10:269-285. doi: 10.1007/s12062-016-9160-4

(2) Holley-Moore G, Hochlaf D, Riaz A. Working for everyone: Addressing barriers and inequalities in the extended working lives agenda. A Research Report from ILC-UK and

the renEWL project. International Longevity Centre - UK (ILC-UK), University College London, Queen Mary University of London; 2017.

(3) Vuorento M, Terävä K. Osatyökykyisen työssä jatkamisen ja työllistymisen tukeminen. Helsinki: Kuntoutussäätiö; 2014.

(4) Taskinen P. Osatyökykyisillä on työhaluja terveysongelmista huolimatta. 
Hyvinvointikatsaus 2012;4. Luettu 12.12.2018. http://www.tilastokeskus.fi/artikkelit/2012/ art_2012-12-10_005.html?s=0

(5) OECD. Sickness, Disability and Work: Breaking the Barriers. A Synthesis of Findings across OECD Countries. Paris: OECD Publishing; 2010. Luettu 13.1.2017. http://ec.europa. eu/health//sites/health/files/mental_health/ eu_compass/reports_studies/disability_ synthesis_2010_en.pdf

(6) ILO code of practice. Managing disability in the workplace. Geneva: International Labor Organization; 2002.

(7) Loo R. Attitudes Toward Employing Persons With Disabilities: A Test of the SympathyDiscomfort Categories. J Appl Soc Psychol 2004;34:2200-2214.

doi: 10.1111/j.1559-1816.2004.tb02697.x

(8) Yelin EH, L. T. Disability and the characteristics of employment. Monthly Labor Review: United States Department of Labor, Bureau of Labor Statistics; 2003. p. 20-31. Luettu 12.12.2018. https://www.bls.gov/opub/mlr/2003/05/art3full. pdf

(9) Reeuwijk KG, van Klaveren D, van Rijn RM, $\mathrm{ym}$. The influence of poor health on competing exit routes from paid employment among older workers in 11 European countries. Scand J Work Environ Health 2017;43:24-33. doi: 10.5271/sjweh.3601

(10) Reeves A, Karanikolos M, Mackenbach J, ym. Do employment protection policies reduce the relative disadvantage in the labour market experienced by unhealthy people? A natural experiment created by the Great Recession in Europe. Soc Sci Med 2014;121:98-108. doi: 10.1016/j.socscimed.2014.09.034

(11) van der Wel KA, Dahl E, Thielen K. Social inequalities in 'sickness': European welfare states and non-employment among the chronically ill. Soc Sci Med 2011;73:1608-1617. doi: 10.1016/j.socscimed.2011.09.012

(12) Kela. Työterveyshuollon korvauksen määrä 2018. Luettu 12.12.2018. https://www.kela.fi/ tyonantajat-tyoterveyshuolto-korvauksen-maara

(13) Suomen perustuslaki, $19 \mathbb{S , ~ ( 1 9 9 9 ) . ~}$

(14) Hietaniemi M, Vidlund M, toim. Suomen eläkejärjestelmä. Helsinki: Eläketurvakeskus; 2003. https://www.julkari.fi/bitstream/ handle/10024/129401/Suomenelakejarjestelma. pdf? sequence $=1$ \&isAllowed $=y$

(15) Keva 2017. Varhe-maksuihin voi vaikuttaa. Luettu 12.12.2018. https://www.keva.fi/ tyonantajalle/elakemaksut/varhe-maksut/

(16) Työterveyshuoltolaki, 21.12.2001/1383, (2001).

(17) Eläketurvakeskus. Suomen työeläkkeensaajat 2016. Tampere: Eläketurvakeskus; 2017.

(18) Keva. Julkisella sektorilla paljon osatyökyvyttömyyseläkkeitä. Helsinki: Keva; 2017. Luettu 12.12.2018. https://www.keva.fi/ uutiset-ja-artikkelit/julkisella-sektorilla-paljonosatyokyvyttomyyselakkeita/
(19) Keva. Työkyvyttömyyseläke ja kuntoutustuki 2017. Luettu 12.12.2018 https://www. keva.fi/henkiloasiakkaalle/tietoa-elakkeista/ elakevaihtoehdot/tyokyvyttomyyselake-jakuntoutustuki/

(20) Keva. Tilastotietoja kunta-alan eläkejärjestelmän eläkkeistä ja vakuutetuista. Helsinki: Keva; 2018. Luettu 12.12.2018. https://www.keva.fi/globalassets/2-tiedostot/ tama-on-keva--tiedostot/tilastotietoja-kuntaalan-elakkeista-2017--ja-vakuutetuista-2017.pdf

(21) Gould R, Kaliva K. Työkyvyttömyyseläke ja ansiotyö. Helsinki: Eläketurvakeskus; 2010.

(22) Snyder LA, Carmichael JS, Blackwell LV, ym. Perceptions of Discrimination and Justice Among Employees with Disabilities. Employ Respons Rights J 2010;22:5-19.

(23) Ervasti J, Vahtera J, Pentti J, ym. Depressionrelated work disability: socioeconomic inequalities in onset, duration and recurrence. PLoS One 2013;8:e79855. doi: 10.1371/journal.pone.0079855

(24) Ervasti J, Kivimaki M, Dray-Spira R, ym. Socioeconomic gradient in work disability in diabetes: evidence from three occupational cohorts. J Epidemiol Community Health 2016;70:125-131. doi: 10.1136/jech-2015-205943

(25) Ervasti J, Kivimaki M, Pentti J, ym. Healthand work-related predictors of work disability among employees with a cardiometabolic disease--A cohort study. J Psychosom Res 2016;82:41-47.

doi: 10.1016/j.jpsychores.2016.01.010

(26) Ervasti J, Kivimaki M, Dray-Spira R, ym. Psychosocial factors associated with work disability in men and women with diabetes: a pooled analysis of three occupational cohort studies. Diabet Med 2016;33:208-217. doi: $10.1111 /$ dme.12821

(27) Koski-Pirilä A. Osatyökyvyttömyyseläkkeiden käyttö kunta-alalla. Helsinki: Keva; 2011.

(28) Kunta10-tutkimus: Työterveyslaitos; 2017. Luettu 12.12.2018. https://www.ttl.fi/ tutkimushanke/kunta10-tutkimus/

(29) Sairaalahenkilöstön hyvinvointitutkimus: Työterveyslaitos; 2018. Luettu 12.12.2018. https://www.ttl.fi/tutkimushanke/ sairaalahenkiloston-hyvinvointitutkimus/

(30) Goldberg DP, Gater R, Sartorius N, ym. The validity of two versions of the GHQ in the WHO study of mental illness in general health care. Psychol Med 1997;27:191-197.

(31) Gould R, Ilmarinen J, Järvisalo J, ym., toim. Dimensions of work ability. Results of the Health 2000 Survey. Helsinki: Finnish Centre for Pensions, The Social Insurance Institution, National Public Health Institute, Finnish Institute of Occupational Health; 2008.

(32) Karasek R. T, T. Healthy work: Stress, Productivity, and the Reconstruction of Working Life. New York: Basic Books; 1990. 
(33) Siegrist J. Adverse health effects of high-effort/ low-reward conditions. J Occup Health Psychol 1996;1:27-41.

(34) Sund R. Methodological Perspectives for Register-Based Health System Performance Assessment: Developing a Hip Fracture Monitoring System in Finland. Helsinki: STAKES; 2008.

(35) Keva. Korvaava työ, osatyökykyiset ja työkykykoordinaattorit kunta-alalla.

Tutkimusseminaari 2017. Luettu 12.12.2018. https://www.keva.fi/globalassets/2-tiedostot/ ta-tiedostot/esitteet-ja-julkaisut/korvaava-tyoosatyokykyiset-ja-tyokykykoodinaattorit-kuntaalalla-seminaarin-diat.pdf

(36) Gragnano A, Negrini A, Miglioretti M, ym. Common Psychosocial Factors Predicting Return to Work After Common Mental Disorders, Cardiovascular Diseases, and Cancers: A Review of Reviews Supporting a Cross-Disease Approach. J Occup Rehabil 2017. doi: 10.1007/s10926-017-9714-1

(37) Kouwenhoven-Pasmooij TA, Burdorf A, RoosHesselink JW, ym. Cardiovascular disease, diabetes and early exit from paid employment in Europe; the impact of work-related factors. Int J Cardiol 2016;215:332-337. doi: 10.1016/j.ijcard.2016.04.090
JENNI ERVASTI

FT, dosentti, erikoistutkija

Työterveyslaitos

LAURA PEKKarinen

VTT, työelämäasiantuntija

Keva

MARIANnA VirTANEN

PsT, Professori

Työterveyslaitos ja Uppsalan yliopisto

Department of Public Health and Caring Sciences

Ville Aalto

FM, erityisasiantuntija

Työterveyslaitos

TuUla OKSANEN

LT, johtava asiantuntija

Työterveyslaitos 